PRACE GEOGRAFICZNE

zeszyt 164, 2021, 1035-126

doi: 10.4467/20833113PG.21.006.13431

Instytut Geografii i Gospodarki Przestrzennej UJ

Komisja Geograficzna, Polska Akademia Umiejętności

Wydawnictwo Uniwersytetu Jagiellońskiego

\title{
INWESTYCJE W KAPITAŁ LUDZKI W RAMACH POLITYKI SPÓJNOŚCI A ROZWÓJ REGIONALNY
}

\author{
Wanda Biedka
}

\section{Investments in human capital within the cohesion policy and their impact on regional development}

Abstract: The aim of this paper is to systematize the existing literature on the effects of cohesion policy and specifically on the effectiveness of public investments in human capital through typology of research. The conclusions are used to give recommendations both for the academic as well as the public sector. There is a need for long-term statistical and macroeconomic analyses as well as in-depth qualitative research on the quality of interventions and differences between different types of investments. While there is a lot of potential in human capital investments to stimulate regional development, they are not a sole key to success and should rather be considered as part of a horizontal and complex development strategy.

Keywords: cohesion policy, human capital, public interventions, regional development

Zarys treści: Celem pracy jest usystematyzowanie wiedzy na temat polityki spójności i inwestycji w kapitał ludzki poprzez opracowanie typologii literatury przedmiotu oraz wypracowanie rekomendacji dla przyszłych badań i zarządzania funduszami. Przegląd wykazał deficyt badań poświęconych inwestycjom w kapitał ludzki w ramach polityki spójności. Istnieje potrzeba zarówno spojrzenia długookresowego, wymagającego analizy statystycznej i makroekonomicznej, jak i pogłębionych badań jakościowych zwracających uwagę na jakość interwencji i ich zróżnicowanie. Wnioski z analizowanych badań pokazują, że chociaż kapitał ludzki ma potencjał do wspierania rozwoju regionalnego, inwestycje w tym obszarze, same w sobie, nie gwarantują sukcesu. Inwestycje w kształcenie i umiejętności powinny znaleźć się w centrum kompleksowych strategii rozwoju.

Stowa kluczowe: polityka spójności, kapitał ludzki, interwencje publiczne, rozwój regionalny 


\section{Wprowadzenie}

Ostatnia dekada postawiła wspólnotę europejską przed szeregiem wyzwań, poczynając od kryzysu ekonomicznego, poprzez Brexit, aż po odpowiedź na pandemię COVID-19 (Bachtler, Begg 2018), prowokując dyskusję nad szeroko rozumianą polityką inwestycyjną Unii oraz polityką spójności (Di Caro i in. 2018; Bachtler, Begg 2018). Jednymi z głównych punktów dyskusji stały się: podnoszenie globalnej konkurencyjności Unii Europejskiej, obniżanie różnic regionalnych, zmiana klimatu, migracje oraz budowanie odporności rynków pracy (Bachtler, Begg 2018). W ślad za tym wzrosło zainteresowanie inwestycjami w kapitał ludzki, które mogą wpływać na produktywność, bezrobocie oraz odporność rynku pracy.

Mierząc się ze zmianami wewnątrz Unii i korektą jej polityki, nie unikniemy pytania: na ile dotychczasowe wsparcie polityki spójności kapitału ludzkiego przyczyniło się do rozwoju regionalnego w Unii i jakie można wyciągnąć z tego wnioski na przyszłość? Niniejszy artykuł ma na celu usystematyzowanie wiedzy na temat efektywności polityki spójności, w szczególności w obszarze inwestycji w kapitał ludzki. Stworzona na tę potrzebę typologia badań ma posłużyć identyfikacji poruszanych w literaturze zagadnień oraz luk badawczych. Wnioski z analizowanych prac pomogą w sformułowaniu rekomendacji dla zarządzania i planowania polityki spójności w przyszłości. Konkluzje te są szczególnie ważne dla Polski, będącej największym beneficjentem polityki spójności w zakończonym niedawno okresie programowania oraz w kontekście wejścia w życie nowego długookresowego budżetu Unii Europejskiej na lata 2021-2027.

W pierwszej części przedstawiono politykę spójności oraz typologię literatury przedmiotu ze względu na poruszany typ zagadnień, następnie opisano wpływ polityki spójności na rozwój regionalny. Drugą część poświęcono roli kapitału ludzkiego w rozwoju regionalnym, a w kolejnej zanalizowano oddziaływanie inwestycji w kapitał ludzki w ramach polityki spójności na rozwój regionalny. Pracę kończy podsumowanie oraz rekomendacje dla dalszych badań naukowych i zarządzania funduszami unijnymi.

\section{Wpływ polityki spójności na rozwój regionalny Unii Europejskiej}

Polityka spójności jest kluczowym instrumentem zmniejszania nierówności między krajami członkowskimi - jednego z głównych celów działania wspólnoty europejskiej (Medve-Bálint 2018). Uważana jest za jedną z najważniejszych polityk europejskich poświęcono jej aż 33\% budżetu unijnego na lata 2014-2020 (Komisja Europejska 2020a). Celem polityki jest stymulowanie spójności gospodarczej, społecznej oraz 
terytorialnej europejskich regionów (Komisja Europejska 2020b). Siedmioletnie okresy programowania różnią się dokładną formą podziału środków, ale główne założenie polityki zakłada wspieranie w różnym zakresie trzech rodzajów regionów najbiedniejszych (PKB poniżej 75\% średniej UE), w okresie przejściowym (PKB między 75\% a 90\% średniej UE) oraz najzamożnieszych (PKB powyżej 90\% średniej UE). W obecnie kończącym się okresie programowania najmniej zamożne regiony dostały ponad połowę środków polityki spójności (Komisja Europejska 2020b).

W latach 2014-2020 polityka spójności wskazywała 11 priorytetów; jednym z nich jest wsparcie edukacji i szkoleń. Główne działania wspierane w ramach tego priorytetu to: inwestycje w infrastrukturę edukacyjną, wspomaganie dostępu do dobrej jakości edukacji oraz ograniczenie przedwczesnego kończenia edukacji, wsparcie kształcenia ustawicznego oraz kształcenia i szkolenia zwodowego (Komisja Europejska 2020c).

Przez ostatnie dwie dekady pojawiło się wiele badań na temat efektywności i wpływu polityki spójności na rozwój gospodarczy w Unii Europejskiej, przynoszących często skrajnie różne wyniki - od bezpośredniego wpływu polityki spójności na rozwój i konwergencję regionów (Maynou i in. 2016) po jego brak lub warunkowość (Rodríguez-Pose, Fratesi 2004; Ederveen i in. 2006). Aby ułatwić czytelnikowi odbiór, w kolejnej części artykułu zaprezentowano typologię podejść badawczych dotyczących mierzenia wpływu polityki spójności na rozwój regionów.

\section{Typologia badań na temat efektywności polityki spójności}

Typologia badań opisana poniżej oraz podsumowana w tabeli 1 uporządkowuje bogaty dorobek literatury naukowej na temat polityki spójności w celu ułatwienia analizy poruszanej problematyki badań i stosowanych metod badawczych oraz identyfikacji luk badawczych w literaturze.

\section{Sposoby rozumienia efektywności polityki spójności}

Bazując na analizie literatury naukowej poświęconej polityce spójności autorstwa Medve-Bálint (2018), rozróżnić można trzy sposoby rozumienia, czym jest efektywność polityki spójności: efektywność wydawania środków (najbardziej popularne podejście, w którym celem badań jest mierzenie wpływu inwestycji na rozwój i konwergencje między krajami lub regionami (Maynou i in. 2016; Fiaschi i in. 2018), zmiany wewnętrzne (mierzenie wpływu inwestycji na zmiany w funkcjonowaniu instytucji publicznych i ich polityki (González-Alegre 2018) oraz dopasowanie do potrzeb - najrzadziej stosowane badania weryfikujące, czy wydatki są adekwatne do potrzeb danego regionu (Medve-Bálint 2018). 
Tab. 1.Typologia badań dotyczących wpływu polityki spójności na rozwój regionalny Table. 1.Typology of research on the impact of cohesion policy on regional development

\begin{tabular}{|c|c|}
\hline Podejścia badawcze / Research approaches & Przykłady opracowań / Examples of studies \\
\hline \multicolumn{2}{|c|}{$\begin{array}{l}\text { Sposoby rozumienia efektywności polityki spójności } \\
\text { Ways of understanding the effectiveness of cohesion policy }\end{array}$} \\
\hline $\begin{array}{l}\text { Efektywność wydawania środków / Effectiveness of spending } \\
\text { funds }\end{array}$ & $\begin{array}{l}\text { Maynou i in. (2016); Fiaschi i in. (2018); } \\
\text { Rodríguez-Pose, Fratesi (2004) }\end{array}$ \\
\hline Zmiany wewnętrzne / Internal changes & González-Alegre (2018) \\
\hline $\begin{array}{l}\text { Dopasowanie wydatków do potrzeb / Matching of the spending } \\
\text { to regional needs }\end{array}$ & Medve-Bálint (2018) \\
\hline \multicolumn{2}{|c|}{ Opracowania metodyczne / Methodical approaches } \\
\hline $\begin{array}{l}\text { Neoklasyczna teoria wzrostu: modele konwergencji, modele } \\
\text { panelowe itd. / Neoclassical growth theory: convergence models, } \\
\text { panel models }\end{array}$ & $\begin{array}{l}\text { Rodríguez-Pose, Fratesi (2004); } \\
\text { Ederveen i in. (2006); Di Caro i in. (2018). }\end{array}$ \\
\hline $\begin{array}{l}\text { Nowa geografia ekonomiczna: panele przestrzenno-czasowe, } \\
\text { przestrzenny model Durbina itd. / New economic geography: } \\
\text { Spatio-temporal panel data models, Durbin model etc. }\end{array}$ & $\begin{array}{l}\text { Maynou i in. (2016); Fiaschi i in. (2018); } \\
\text { Mohl, Hagen (2010); González-Alegre } \\
\text { (2018) }\end{array}$ \\
\hline $\begin{array}{l}\text { Metody jakościowe i mieszane: przeglądy literatury, wywiady, } \\
\text { badania mikroekonomiczne / Qualitative and mixed methods: } \\
\text { literature reviews, interviews, microeconomic studies }\end{array}$ & Wojnar (2011); Pelucha i in. (2019) \\
\hline $\begin{array}{l}\text { Badania ewaluacyjne: TIA, Hermin model / Evaluation studies: TIA, } \\
\text { Hermin model }\end{array}$ & $\begin{array}{l}\text { Medeiros (2014, 2017); Bradley (2006); } \\
\text { Gorzelak (2014) }\end{array}$ \\
\hline \multicolumn{2}{|c|}{ Mierniki sukcesu / Measures of success } \\
\hline $\begin{array}{l}\text { Wzrost gospodarczy: Produkt krajowy brutto i jego pochodne } \\
\text { Economic growth: GDP and its derivatives }\end{array}$ & $\begin{array}{l}\text { Fiaschi i in. (2018); Maynou i in. (2016); } \\
\text { Rodríguez-Pose, Fratesi (2004) }\end{array}$ \\
\hline $\begin{array}{l}\text { Złożone miary rozwoju gospodarczego / Complex measures } \\
\text { of economic development }\end{array}$ & Medeiros (2017); Caldas i in. (2018) \\
\hline $\begin{array}{l}\text { Alternatywne miary efektywności polityki: spójność społeczna, } \\
\text { stabilność rynku pracy, wyniki przedsiębiorstw } \\
\text { Alternative measures of policy effectiveness: social cohesion, } \\
\text { stability of the labour market, enterprise economic performance }\end{array}$ & $\begin{array}{l}\text { Wojnar (2011) ; Di Caro i in. (2018); } \\
\text { Pelucha i in. (2019) }\end{array}$ \\
\hline \multicolumn{2}{|c|}{ Skala analizy / Scale of the analysis } \\
\hline $\begin{array}{l}\text { Regionalna (NUTS } 1 \text { lub } 2 \text { w badaniach międzynarodowych) } \\
\text { Regional (NUTS } 1 \text { or } 2 \text { in the international studies) }\end{array}$ & $\begin{array}{l}\text { Maynou i in. (2016) ; Rodríguez-Pose, } \\
\text { Fratesi (2004) }\end{array}$ \\
\hline $\begin{array}{l}\text { Lokalna (Poniżej NUTS } 2 \text { najczęściej w badaniach na poziomie } \\
\text { kraju lub regionu) / Local (Below NUTS } 2 \text { most often in national } \\
\text { or regional studies) }\end{array}$ & Churski i in. (2016) \\
\hline \multicolumn{2}{|c|}{ Czynniki mające wpływ na efektywność środków / Factors affecting the effectiveness of the funds } \\
\hline $\begin{array}{l}\text { Poziom rozwoju regionu, jakość rządzenia / Regional development } \\
\text { level, governance quality }\end{array}$ & $\begin{array}{l}\text { Maynou I in. (2016); Fiaschi i in. (2018); } \\
\text { Ederveen i in. (2006) }\end{array}$ \\
\hline $\begin{array}{l}\text { Rodzaj, ilość i sposób wydawania środków / Type, quantity } \\
\text { and way of spending of the funding }\end{array}$ & $\begin{array}{l}\text { Fiaschi i in. (2018); Cerqua i Pellegrini } \\
\text { (2018); Medve-Bálint (2018) }\end{array}$ \\
\hline
\end{tabular}




\begin{tabular}{|l|l|}
\hline \multicolumn{1}{|c|}{ Podejścia badawcze / Research approaches } & Przykłady opracowań / Examples of studies \\
\hline $\begin{array}{l}\text { Inne: zaprzestanie wsparcia; sytuacja przedsiębiorstw przed } \\
\text { uzyskaniem wsparcia; struktura sieci osadniczej / Other: ending } \\
\text { of the support, situation of enterprises before the support, } \\
\text { structure of settlement network }\end{array}$ & $\begin{array}{l}\text { Di Cataldo (2017); Becker i in. (2018); } \\
\text { sPelucha i in. (2019); Medeiros (2017) }\end{array}$ \\
\hline \multicolumn{2}{|c|}{ Conclusions - the role of cohesion policy in the development of the EU } \\
\hline $\begin{array}{l}\text { Inwestycje polityki spójności mają wpływ na konwergencję } \\
\text { regionów / Cohesion policy investments have an impact } \\
\text { on the regional convergence }\end{array}$ & Maynou i in. (2016) \\
\hline $\begin{array}{l}\text { Polityka spójności ma warunkowy wpływ na konwergencje } \\
\text { regionów / Cohesion policy has a conditional impact on regional } \\
\text { convergence }\end{array}$ & $\begin{array}{l}\text { Rodríguez-Pose, Fratesi (2004); } \\
\text { Ederveen i in. (2006) }\end{array}$ \\
\hline $\begin{array}{l}\text { Efektywność polityki spójności, rządzi się prawami malejących } \\
\text { marginalnych zysków / The effectiveness of cohesion policy } \\
\text { is governed by the laws of diminishing marginal returns }\end{array}$ & Fiaschi i in. (2018) \\
\hline $\begin{array}{l}\text { Zakończenie wsparcia finansowego ma negatywny wpływ } \\
\text { na rozwój regionu / The termination of financial support has } \\
\text { a negative impact on the development of the region }\end{array}$ & Di Cataldo (2017) \\
\hline $\begin{array}{l}\text { Pewne rodzaje inwestycji mają pozytywny wpływ na jakość życia, ale } \\
\text { nie mają wpływu na rozwój regionu / Certain types of investments } \\
\text { have a positive effect on the quality of life but do not affect the } \\
\text { development of the region }\end{array}$ & Gorzelak (2014); Kozak (2014) \\
\hline
\end{tabular}

\section{Opracowanie metodyczne}

W literaturze znaleźć można trzy podstawowe rodzaje metod - ilościowe, jakościowe i mieszane oraz metody ewaluacyjne. Najbardziej popularna kategoria to metody ilościowe, stosowane zazwyczaj do badań na poziomie międzynarodowym. Wybór metodologii zależy od przyjmowanych teorii rozwoju regionalnego. Wnioski z tego przeglądu literatury potwierdzone przez Dall'Erba, Fang (2017) wskazują, że dominującym podejściem jest neoklasyczna teoria wzrostu zakładająca „Malejący zwrot z kapitału oraz stałe i egzogeniczne tępo postępu technologicznego" (Dall'Erba, Fang 2017, s. 823). Przekłada się to na popularność typowych dla tej teorii metod: modelu beta konwergencji oraz modeli panelowych badających wpływ interwencji publicznej na rozwój w miarę upływu czasu (Rodríguez-Pose, Fratesi 2004; Ederveen i in. 2006). Badania wpisujące się w ten nurt co prawda pozwalają na porównywanie efektów polityki spójności w różnych krajach członkowskich, ale ze względu na swój ogólny charakter ich wnioski nie są szczególnie pomocne w formułowaniu konkretnych rekomendacji dla projektowania i zarządzania funduszami.

Rośnie także zainteresowanie przestrzennym podejściem pochodzącym od nowej geografii ekonomicznej - nurtu badań zwracającego uwagę na relacje między rdzeniem rozwoju a peryferiami (Mohl, Hagen 2010). Podejście przestrzenne pozwala 
na uwzględnienie przestrzennych efektów zewnętrznych inwestycji. Przykłady przestrzennych modeli zastosowanych w artykułach omówionych w tej pracy to: panele przestrzenno-czasowe, modele Solowa dopełnione o przestrzenny aspekt lub przestrzenny model Durbina (Maynou i in. 2016; Fiaschi i in. 2018; Mohl, Hagen 2010; González-Alegre 2018). Metody przestrzenne wydają się obecnie najbardziej obiecującym podejściem ekonometrycznym, ponieważ pozwalają na ocenę efektywności polityki spójności, odwzorowując zależności przestrzenne i dynamikę efektów interwencji publicznych.

Pozostałe dwie kategorie metodologii to: metody jakościowe i mieszane oraz metody ewaluacyjne. Oba podejścia zazwyczaj stosowane są na potrzeby badań na poziomie narodowym, regionalnym lub lokalnym. Metody jakościowe i mieszane to najczęściej przeglądy literatury, wywiady oraz ankiety wśród aktorów zaangażowanych w realizowanie polityki lub jej beneficjentów.

Badania ewaluacyjne czerpią z kultury ewaluacji promowanej przez Komisję Europejską i składają się z metod jakościowych i ilościowych. W omawianych artykułach zastosowano dwa przykłady metod ewaluacyjnych: Territorial Impact Assessment (TIA) oraz Hermin model. TIA to rodzaj metodologii ewaluacji polityki spójności, w której przestrzennej analizie poddane są efekty polityki spójności (Medeiros 2017). Model Hermin pozwala na średniookresową ewaluację wpływu funduszy strukturalnych, a w szczególności inwestycji w infrastrukturę fizyczną oraz zasoby ludzkie (Bradley 2006). Badania ewaluacyjne pozwalają na szczegółową analizę różnych wymiarów efektywności funduszy europejskich oraz dają podstawę do tworzenia praktycznych rekomendacji dla instytucji unijnych oraz regionalnych i państwowych instytucji implementujących programy unijne.

\section{Mierniki sukcesu}

W związku z tym, że najbardziej popularnym podejściem w literaturze polityki spójności jest mierzenie efektywności środków unijnych w stymulacji rozwoju, najbardziej popularną miarą sukcesu inwestycji jest rozwój gospodarczy. Wśród przeanalizowanych badań najczęściej spotykanym miernikiem rozwoju jest produkt krajowy brutto i jego pochodne (np. Fiaschi i in. 2018; Maynou i in. 2016; Rodríguez-Pose, Fratesi 2004). Naukowcy używają również złożonych miar rozwoju, zależnych od specyfiki każdego z badań (Medeiros 2017; Caldas i in. 2018). Rozwój gospodarczy nie jest jednak jedyną miarą efektywności polityki spójności - badacze brali również pod uwagę spójność społeczną (Wojnar 2011) lub stabilność rynku pracy (Di Caro i in. 2018), a w przypadku Pelucha i in. (2019) - wyniki biznesowe przedsiębiorstw. 


\section{Skala analizy}

Znaczna większość analizowanych badań została przeprowadzona na wysoko zagregowanym poziomie państw lub regionów (NUTS2). Tłumaczyć ten fakt może dostępność danych oraz ich jakość, która dopiero przez ostatnie 10 lat znacząco się poprawiła (Dall'Erba, Fang 2017). Jak zostało to już wcześniej podkreślone, badania w większej skali na poziomie NUTS2 to często badania międzynarodowe stosujące modele panelowe. Natomiast badania na poziomie lokalnym częściej dają bardziej szczegółowy obraz efektywności środków polityki spójności w jednym kraju poprzez stosowanie metod mieszanych.

\section{Czynniki mające wpływ na efektywność środków}

Jedynym z najczęściej analizowanych czynników efektywności środków unijnych jest poziom rozwoju badanego obszaru (regionu, gminy). Jest on często zoperacjonalizowany przez rozróżnienie kategorii regionów otrzymujących wsparcie z polityki spójności (Maynou i in. 2016; Fiaschi i in. 2018). Oprócz gospodarczego ujęcia poziomu rozwoju badane są także związki między jakością zarządzania i administracji w danym regionie (np. Ederveen i in. 2006).

Drugą ważną kategorią czynników są: rodzaj, ilość i sposób wydawania środków. Po pierwsze, badana jest efektywność wydatków w różnych obszarach - infrastruktura fizyczna, ochrona środowiska albo kapitał ludzki. Po drugie, istotnym czynnikiem dla badaczy jest intensywność wydatków i absorbcja środków (Fiaschi i in. 2018; Cerqua, Pellegrini 2018). Po trzecie, pewna grupa badaczy zaczęła zwracać uwagę na dopasowanie środków do potrzeb regionu (Medve-Bálint 2018).

Do innych czynników efektywności środków unijnych można także zaliczyć m.in.: wycofanie wsparcia jako negatywny czynnik rozwój regionu (Di Cataldo 2017; Becker i in. 2018), sytuację przedsiębiorstw przed uzyskaniem wsparcia (Pelucha i in. 2019) oraz strukturę sieci osadniczej (Medeiros 2017).

\section{Wnioski - rola polityki spójności w rozwoju UE}

Wyróżnić można pięć głównych kategorii wniosków na temat roli polityki spójności w rozwoju UE: (1) inwestycje polityki spójności mają wpływ na konwergencję regionów (np. Maynou i in. 2016); (2) polityka spójności ma warunkowy wpływ na konwergencję (czynniki warunkujące efektywność to m.in. rodzaj inwestycji, poziom rozwoju regionu itd.) (np. Rodríguez-Pose, Fratesi 2004; Ederveen i in. 2006); (3) efektywność polityki spójności rządzi się prawami malejących marginalnych zysków (np. Fiaschi i in. 2018); (4) zakończenie wsparcia finansowego ma negatywny wpływ na rozwój regionu (np. Di Cataldo 2017); oraz (5) pewne rodzaje 
inwestycji mają pozytywny wpływ na jakość życia, ale nie wpływają na rozwój regionu (np. Gorzelak 2014).

\section{Przegląd wybranych badań na temat efektywności polityki spójności}

Głównym zadaniem polityki spójności jest wspieranie rozwoju regionalnego i lokalnego, aby niwelować różnice w produktywności oraz dobrobycie między krajami członkowskimi. Analiza wpływu polityki na konwergencję między krajami i regionami Unii jest więc jednym ze sposobów oceny jej efektywności. Według Maynou i in.(2016) wydatki na politykę spójności w krajach strefy euro w latach 1990-2010 osiągnęły oczekiwane efekty, prowadząc do zmniejszenia się różnic w rozwoju. Stosując przestrzenno-czasowy model ekonometryczny, oprócz danych na temat poziomu PKB, autorzy badania wzięli również pod uwagę podobieństwo regionów (poziom NUTS2) położonych bliżej siebie oraz wpływ okresu, w którym wyniki zostały zebrane. Analiza wykazała konwergencje beta PKB per capita.

Oprócz pracy Maynou i in. (2016) istnieje jednak stosunkowo niewiele analiz, które wykazują bezwarunkowo pozytywne efekty polityki spójności. Według głośnej pracy Rodríguez-Pose i Fratesi (2004) efektywność polityki spójności zależy od celu wydawania środków. W badaniach zastosowano model regresji dla okresu 1989-1999 wśród najbiedniejszych regionów oraz reszty regionów ówczesnej Unii na poziomie NUTS2. Model pozwolił zbadać relację między PKB per capita oraz ilością wydanych środków wyrażonych jako procent regionalnego PKB. Wydatki podzielono na cztery kategorie: wsparcie rolnictwa i obszarów wiejskich; wsparcie biznesu i turystyki; inwestycje w edukację, zdobywanie kwalifikacji i inne inwestycje w kapitał ludzki; oraz inwestycje w transport, infrastrukturę i środowisko (Rodríguez-Pose, Fratesi 2004). Badania wskazały na brak wpływu inwestycji w infrastrukturę fizyczną oraz ograniczony wpływ wsparcia dla biznesu na rozwój regionu, w przeciwieństwie do inwestycji w kapitał ludzki.

Do podobnych wniosków doszli również polscy naukowcy. Gorzelak (2014) oraz Kozak (2014) argumentują, że chociaż fundusze unijne przyniosły w Polsce poprawę jakości życia, to nie widać związku między wsparciem Unii a rozwojem regionalnym. Wnioski te potwierdzają również badania Churskiego i in. (2016) nad absorbcją środków unijnych w polskich ośrodkach regionalnych i powiatach. Zespół przeanalizował wyniki badań ankietowych przeprowadzonych wśród władz regionalnych oraz modele korelacji i regresji między poziomem rozwoju danego ośrodka regionalnego lub powiatu oraz absorbcją środków, rodzajem funduszy, z których zostały pozyskane, oraz celem, na który zostały przeznaczone. Wyniki pokazały, że środki unijne koncentrują się w ośrodkach regionalnych, a fundusze przeznaczane są głównie na inwestycje podnoszące jakość życia, czyli te z zakresu ochrony środowiska i transportu. 
Innym warunkiem efektywności może być też jakość zarządzania i otoczenia administracyjnego, które wykazali Ederveen i in. (2006), a ostatnio również Fratesi, Wishlade (2017). Potencjał rozwojowy środków unijnych kształtować może też kontekst prawny w danym kraju, czego dowodzi, na przykładzie Portugalii, Medeiros (2014). Z jednej strony zastosowany rodzaj metody TIA wskazał na pozytywny wpływ polityki spójności na rozwój społeczno-gospodarczy. Szczególnie skuteczne okazały się m.in. inwestycje w kapitał ludzki oraz wsparcie zatrudnienia i walki z bezrobociem. Z drugiej strony, wyniki prowadzą Medeiros (2014) do wniosku, że w przyszłości powinna powstać stabilna podstawa prawna w formie polityki przestrzennej i strategii rozwoju, aby skuteczniej kierować rozwojem i wydatkami w ramach polityki spójności.

Istnieją również prace, które wskazują na uzależnienie skuteczności polityki spójności od rodzaju obszaru objętego pomocą. Fiaschi i in. (2018) oraz Mohl i Hagen (2010) dowodzą, że polityka spójności wpływa jedynie na rozwój regionów najgorzej rozwiniętych. W pracy Mohl i Hagen (2010) zastosowano metodę panelowo-przestrzenną, badając rejony NUTS 1 i NUTS 2 między rokiem 2000 a 2006. Wyniki analizy wykazały brak wpływu polityki spójności na najzamożniejsze regiony oraz te w okresie przejściowym. Potwierdzony został natomiast wpływ polityki spójności na najbiedniejsze regiony oraz pozytywne efekty zewnętrzne w Europie Zachodniej. Fiaschi i in. (2018) doszli do podobnego wniosku, używając przestrzennego modelu wzrostu Solowa ${ }^{1}$, w którym wskaźnikiem rozwoju było PKB na pracownika, a badaniem objęte były regiony UE-12² między rokiem 1991 a 2008.

Czynnikiem warunkującym efektywność wsparcia może być także jego wartość. Fiaschi i in. (2018) podkreślają, że nawet w regionach słabiej rozwiniętych wsparcie polityki spójności na poziomie powyżej 4\% PKB przestaje mieć dodatkowy wpływ. Motyw zmniejszającego się zysku z polityki spójności pojawia się również w badaniach Cerqua i Pellegrini (2018). Przedmiotem badań były regiony UE-15 ${ }^{3}$ oraz wpływ intensywności finansowania w ramach polityki spójności na ich rozwój w latach 1994-2000. Analiza regresji pozwoliła na obliczenie progu funduszy unijnych: 305-340 euro per capita, po którego przekroczeniu wartość dodana z każdego kolejnego euro przestaje rosnąć.

Pogłębiając kwestie wpływu polityki spójności na regiony najgorzej rozwinięte, Bradley (2006) wykonał analizę oddziaływania funduszy spójności na regiony Europy Środkowo-Wschodniej oraz regiony Południa Unii (Hiszpania, Portugalia, Grecja).

\footnotetext{
${ }^{1}$ Model Solowa to neoklasyczny model egzogenicznego wzrostu gospodarczego, w którym czynnikiem wpływającym na wzrost gospodarczy jest egzogeniczny postęp techniczny (Telega 2012).

${ }^{2}$ UE 12 (1993 r. - 1994 r.): Belgia, Dania, Francja, Niemcy, Grecja, Irlandia, Włochy, Luksemburg, Holandia, Portugalia, Hiszpania i Wielka Brytania (Eurostat 2020).

${ }^{3}$ UE 15 (1995 r. - 2004 r. ): Belgia, Dania, Francja, Niemcy, Grecja, Irlandia, Włochy, Luksemburg, Holandia, Portugalia, Hiszpania, Wielka Brytania, Austria, Finlandia i Szwecja (Eurostat 2020).
} 
Zastosowanie modelu Hermin wykazało, że polityka spójności przyniosła największe efekty mnożnikowe w Hiszpanii i Polsce. Na efektywność wpływa jednak jakość interwencji - te źle zaplanowane lub przeprowadzone charakteryzują się mniejszą elastycznością efektów zewnętrznych. Dodatkowo, w badaniach Bradley’a (2006) pojawia się kwestia wyciszania efektów interwencji po jej zaprzestaniu - widoczny jest wpływ zakończenia wspierania na poziom PKB (ale nie tempo wzrostu gospodarczego).

Jak pokazują badania Bradley’a (2006), wpływ na rozwój regionu ma też wycofanie środków. Di Cataldo (2017) przyjrzał się tej kwestii na przykładzie dwóch brytyjskich regionów: Kornwalii i Południowego Yorkshire. Zbadany został wpływ środków w trakcie i po zaprzestaniu wsparcia dla regionów najbiedniejszych. Miarą efektów polityki stały się poziom bezrobocia i PKB per capita. Wyniki analizy wykazały, że chociaż wsparcie w ramach pomocy dla najmniej zamożnych regionów zmniejszyło poziom bezrobocia oraz różnice w dochodach między Yorkshire i Kornwalią a bardziej zamożnymi regionami, pozytywne skutki inwestycji zaczęły zanikać po zaprzestaniu wsparcia. Podobny wynik uzyskał również zespół Becker i in. (2018) analizujacy oddziaływanie polityki spójności na rozwój regionów NTUS 2. Wyniki analizy metodą nieciągłego modelu regresji pokazują, że pozytywny wpływ polityki spójności nie utrzymuje się długo po zakończeniu okresu programowania. Ponadto, według Becker i in. (2018) polityka spójności miała ograniczony wpływ w krajach najmocniej dotkniętych kryzysem ekonomicznym.

Należy zwrócić uwagę na różnorodność metod stosowanych w wyżej wymienionych badaniach: od modeli regresji poprzez bardziej złożone modele przestrzenne, co wpłynęło na rozbieżność wyników. Odnotować należy jednak relatywnie małą liczbę badań używających danych w skali lokalnej (poniżej NUTS2). Biorąc pod uwagę, że konkretne inwestycje realizowane są na poziomie lokalnym, dopiero badania w skali podregionalnej mają szansę na odwzorowanie dynamiki interwencji publicznych.

\section{Wpływ kapitału ludzkiego na rozwój regionalny}

Zainteresowanie związkiem między kapitałem ludzkim a rozwojem regionalnym sięga późnych lat 50. XX w. Pierwsze prace skupiały się na definiowaniu, czym jest kapitał ludzki, oraz na pierwszych modelach związku między nim a rozwojem. Na przykład, Mincer (1958) definiował kapitał ludzki przez długość wykształcenia oraz doświadczenia zdobywanego podczas pracy, jego model pokazał, że „zawody wymagające dłuższej nauki zapewniają wyższą płacę” (Cichy, Malaga 2007, s. 20). W latach 60. zaczęto stosować także pojęcie kapitału ludzkiego do rewizji neoklasycznych teorii rozwoju, takich jak teoria egzogenicznego wzrostu Solowa, która przyjmuje, że akumulacja kapitału fizycznego jest czynnikiem rozwoju gospodarczego 
(Mankiw i in. 1992). Prace Uzawy (1965) oraz Nelsona i Phelpsa (1966) przypisywały jednak większą rolę kapitałowi ludzkiemu.

Dwie dekady później Lucas (1988) wykazał wpływ wykształcenia oraz szkolenia podczas pracy na rozwój gospodarczy i rozróżnił dwa rodzaje efektów, jakie zapewnia kapitał ludzki - wewnętrzne (sposób, w jaki kapitał ludzki wpływa na życie jednostek) oraz zewnętrzne (wpływ na społeczeństwo i rozwój gospodarczy). Kluczowym elementem pracy Lucasa (1988) było rozwinięcie dyskusji na temat roli kapitału ludzkiego w neoklasycznej teorii rozwoju poprzez skonstruowanie trzech modeli, opisujących różne aspekty działania kapitału ludzkiego: „akumulację kapitału fizycznego i postęp techniczny, akumulację kapitału ludzkiego poprzez szkolnictwo oraz akumulację specjalistycznego kapitału ludzkiego wskutek zdobywania doświadczenia" (Cichy, Malaga 2007, s. 28). Warto przytoczyć także pracę zespołu Mankiw i in. (1992), która również odnosiła się do neoklasycznego modelu Solowa. Zespół ten opracował model uwzględniający akumulację kapitału ludzkiego do dziś przydatny w badaniach nad tym zagadnieniem.

Współcześni naukowcy kontynuują badania przedmiotu w różnych skalach (międzynarodowej, regionalnej lub lokalnej) i analizują relację między kapitałem ludzkim a rozwojem. Czerpiąc z dorobku ostatnich 80 lat, wychodzi się obecnie poza analizę roli kapitału w neoklasycznych modelach wzrostu i bada się nie tylko jego wpływ na rozwój, lecz także na bezrobocie czy migracje.

Wpływ na wzrost gospodarczy wykazały także badania Cuaresma i in. (2018). Bazując na przestrzennym modelu Durbina ${ }^{4}$, szukano czynników wyjaśniających wzrost gospodarczy europejskich regionów na poziomie NUTS 2. Wyniki pokazują, że kapitał ludzki jest ważnym czynnikiem konwergencji dochodów per capita między zamożnymi i biednymi regionami oraz wzrostu gospodarczego, szczególnie wśród regionów słabiej rozwiniętych (wynik potwierdza więc wcześniejsze badania wykazujące większe znaczenie kapitału ludzkiego dla słabiej rozwiniętych regionów, np. Di Liberto, J. Symonsa (2001), Herbst 2007a).

Sytuacja wygląda jednak inaczej, jeżeli spojrzy się na produktywność na poziomie rozwoju regionalnego. Gennaioli i in. (2013) przeanalizowali dane ze 110 krajów z całego świata oraz paru tysięcy firm. Badania połączyły dwa modele stworzone przez Roberta Lucasa, tworząc nowy, przestrzenny model „Lucas-Lucas”. Celem modelu było określenie, w jaki sposób rozwój regionalny kształtowany jest przez różne czynniki (m.in. warunki geograficzne, jak klimat czy położenie, zasoby naturalne, instytucje), w tym kapitał ludzki rozumiany jako wykształcenie pracowników oraz wykształcenie przedsiębiorców. Wzięta pod uwagę została również międzyregionalna mobilność pracowników, firm i przedsiębiorców. Badania wykazały, że wykształcenie

${ }^{4}$ Przestrzenny model Durbina to rodzaj przestrzennego modelu ekonometrycznego uwzględniający zależność czynników egzo- i endogenicznych (Cuaresma i in. 2018). 
przedsiębiorców ma większe znaczenie - to oni tworzą nowe przedsiębiorstwa i miejsca pracy oraz mają wpływ na ich produktywność (Gennaioli i in. 2013).

Pozytywny wpływ kapitału ludzkiego na rozwój wykazały również europejskie badania regionów na poziomie NUTS 1 między 2000 a 2013 r. (Männasoo i in. 2018). Tym razem został zastosowany model wzrostu Schumpetera z uwzględnieniem przestrzennych efektów zewnętrznych ${ }^{5}$. Badania wykazały pozytywny wpływ kapitału ludzkiego oraz inwestycji w B+R (badania i rozwój) na ogólną wydajność czynników produkcji. Co więcej, największa wartość dodana z przyrostu zasobów kapitału ludzkiego i inwestycji w B+R pojawia się w krajach słabiej rozwiniętych. Jednak w państwach tych to właśnie ich najbardziej rozwinięte regiony zyskują najwięcej z inwestycji w kapitał ludzki i B+R. Gorzej wypadły regiony dobrze rozwiniętych krajów, gdzie wartość dodana inwestycji w kapitał ludzki spadła. Podsumowując, wzrost poziomu kapitału ludzkiego ma większy wpływ na regiony słabiej rozwinięte, ale z już istniejącą bazą zasobów ludzkich, technologii oraz instytucji wspierających innowacje i biznes.

Ważnym aspektem rozwoju regionalnego, oprócz dochodów oraz produktywności, jest poziom bezrobocia. Tu również zasoby kapitału ludzkiego mogą okazać się znaczące. Di Cataldo i Rodríguez-Pose (2017) zbadali jak na zatrudnienie wysokoi nisko-wykwalifikowanych pracowników oraz redukcję długookresowego bezrobocia oddziałują: stan kapitału ludzkiego, innowacje, infrastruktura oraz jakość rządzenia. Dane zostały wprowadzone do dwóch modeli - efektów stałych i losowych, oraz do dynamicznego panelu autoregresyjnego $\operatorname{AR}(1)^{6}$. W regionach bardziej rozwiniętych to właśnie kapitał ludzki oraz innowacyjność w regionie pozytywnie wpływały na zatrudnienie wyżej wykształconych pracowników. Niestety relacja ta nie przekłada się na sytuację najbardziej wrażliwej grupy pracowników - tych z niskimi kwalifikacjami. Wnioski prowadzą autorów do refleksji, że inwestycje w kapitał ludzki są potrzebne, ale niewystarczające. W przypadku najgorzej rozwiniętych regionów z niskimi zasobami kapitału ludzkiego podobne programy mogą przynieść ograniczone efekty.

Wyniki badań nad kapitałem ludzkim kształtowane są przez zastosowaną metodologię i jakość danych. Po pierwsze, ma na nie wpływ przyjęta definicja i operacjonalizacja pojęcia kapitału ludzkiego - czy kapitał ludzki jest pochodną wykształcenia, czy może doświadczenia zawodowego, jakie poziomy edukacji są brane pod uwagę itd. (Herbst 2007a). Ponadto w przypadku międzynarodowych analiz porównawczych bazujących na danych dotyczących jakości edukacji (np. porównania wyników

\footnotetext{
${ }^{5}$ Podstawą modelu wzrostu Schumpetera jest założenie, że długookresowy wzrost gospodarczy wynika z innowacji będących efektem inwestycji przedsiębiorców (Aghion i in. 2015).

${ }^{6}$ dynamiczny panel autoregresyjny AR - „model używany do reprezentowania szeregów czasowych, w którym każda kolejna obserwacja zależy, przynajmniej częściowo, od jednej lub więcej wcześniej zaobserwowanych wartości." (APA 2020).
} 
egzaminów) trzeba brać pod uwagę różnice w systemach edukacji oraz jakości danych w różnych krajach (Cohen, Soto 2007).

Różnice wyników ze względu na definicję i rodzaj danych dobrze ilustrują badania Herbsta (2007b). Ogólne wyniki wskazują, że zasoby kapitału ludzkiego, mierzone jako przeciętny czas trwania nauki szkolnej oraz procent populacji z co najmniej średnim wykształceniem, mają pozytywny wpływ na dochód podregionów. Jednak nie każdy rodzaj wykształcenia wpływa tak samo na regionalne PKB - o ile odsetek absolwentów liceów ogólnokształcących ma pozytywny wpływ, o tyle odsetek absolwentów zawodowych szkół średnich i techników ma charakter negatywny. Ogólne wyniki badań potwierdziły natomiast, że regiony z istniejącym kapitałem ludzkim rozwijały się szybciej (Herbst 2007b). Zróżnicowanie pierwotnego poziomu kapitału ludzkiego oraz tempa wzrostu gospodarczego powoduje dywergencję poziomu rozwoju między obszarami o najwyższym kapitale ludzkim (metropoliami) a resztą kraju.

W literaturze na temat roli inwestycji w kapitał ludzki w rozwoju regionalnym można znaleźć też bardziej sceptyczne głosy. Począwszy od tych wykazujących ich ograniczony wpływ, po te wskazujące na negatywny wpływ inwestycji w kapitał ludzki na gospodarkę regionu. Wzrost poziomu wykształcenia w miejscu mniej rozwiniętym gospodarczo i z mniejszymi szansami na osobisty rozwój prowadzi często do zjawiska nazywanego „drenażem mózgów” (ang. braindrain), czyli emigracji pracowników z wyższym kapitałem ludzkim do ośrodków wyżej rozwiniętych (Herbst, Rok 2013). Inwestycje w kapitał ludzki mogą więc prowadzić do pogłębiania się różnic międzyregionalnych.

\section{Wpływ inwestycji w kapitał ludzki w ramach polityk i spójności na rozwój regionalny}

W okresie programowania 2007-2013 inwestycje w kapitał ludzki stanowiły czwartą, największą, kategorię wydatków polityki spójności (30 mld euro) (Komisja Europejska 2013). Komisja Europejska szacuje, że dzięki krajowym programom operacyjnym polityki spójności do 2011 r. w całej Unii Europejskiej zostało stworzonych 40 tys. nowych miejsc pracy, a dzięki europejskiemu funduszowi społecznemu między 2007 a 2011 r. 2,4 mln osób znalazło pracę w czasie krótszym niż 6 miesięcy od momentu wzięcia udziału w fundowanych programach (Komisja Europejska 2013). Tak wyglądają statystki przedstawiane przez Komisję Europejską. W literaturze naukowej natomiast oceny wpływu inwestycji w kapitał ludzki na rozwój regionów Unii Europejskiej są różne. Tematyka badań obejmuje: inwestycje wspierające walkę z bezrobociem młodych (O’Reilly i in. 2015), aktywną politykę rynku pracy (González-Alegre 2018), inwestycje w jakość edukacji i aktywizację zawodową (Wojnar 2011) oraz szkolenia (Pelucha i in. 2019). 
Patrząc na całość polityki spójności w Hiszpanii, Medeiros (2017) wykazał umiarkowanie pozytywny wpływ polityki. Wśród różnych kierunków wsparcia wyróżniały się między innymi inwestycje w infrastrukturę społeczną (np. szkolenia zawodowe) wspierające społeczno-gospodarczy rozwój regionów. Wyniki uzyskano przez wielowymiarową i wielowektorową ocenę wpływu, badając pierwsze cztery okresy programowania polityki spójności w Hiszpanii od 1989 do 2013 r. Podobne wyniki uzyskał również wcześniej wspomniany Medeiros (2014), stosując model TARGET_TIA ${ }^{7}$ dla portugalskich regionów.

Do odmiennych wniosków doszli natomiast Caldas i in. (2018). Przedmiotem badań były portugalskie jednostki samorządowe między 2000 a 2014 r. W badaniach zastosowano analizę przepływów międzygałęziowych ${ }^{8}$, w której badano efekty różnych kategorii inwestycji (konkurencyjność, waloryzacja terytorialna i potencjał ludzki), biorąc pod uwagę położenie oraz sytuację finansową i poziom rozwoju jednostek samorządowych (Caldas i in. 2018). Istotny dla tej pracy wydaje się wynik dotyczący inwestycji w „potencjał ludzki” (m.in. inwestycje w szkolenia i edukację szkolną oraz infrastrukturę edukacyjną). Pomimo sporych wydatków w tej kategorii, nie wpłynęły one znacząco na poziom kwalifikacji, jakość oraz efektywność edukacji i nie poprawiły stanu dopasowania kwalifikacji pracowników do potrzeb rynkowych. Autorzy podsumowują badania twierdzeniem, że wpływ na zrównoważony rozwój jednostek samorządowych miały głównie inwestycje w waloryzację terenów i konkurencyjność.

Bardziej zbliżone wnioski do wyników Medeiros (2014) wypłynęły z badań Wojnar (2011) na temat wpływu polityki spójności na spójność społeczną w polskich miastach. Badania oparte na metodach mieszanych wykazały, że największe efekty przyniosły interwencje z zakresu poprawy jakości edukacji oraz aktywizacji zawodowej osób biernych zawodowo i długotrwale bezrobotnych, zaś grupami, które najwięcej skorzystały na polityce spójności okazały się kobiety oraz uczniowie, studenci i absolwenci (Wojnar 2011). Należy jednak podkreślić, że wyniki wykazały brak wpływu interwencji w zakresie polityki spójności na całościową poprawę spójności społecznej.

Oprócz bezpośredniego wpływu na wskaźniki rozwoju społeczno-gospodarczego kapitał ludzki może przyczynić się do poprawy odporności regionu na szoki gospo-

\footnotetext{
${ }_{7}$ TARGET_TIA - to rodzaj modelu oceny oddziaływania terytorialnego (territorial impact assessement) sporządzonego przez autorów badania. W pracy sprawdzano, w jaki sposób interwencje w ramach polityki spójności wpłynęły na cztery wymiary spójności terytorialnej: spójności społeczno-gospodarczej, zrównoważonego rozwoju środowiska, zarządzania i współpracy oraz „morfologicznej policentryczności” (charakterystyka sieci osadniczej). Zmiany oceniane były na czterech osiach: pozytywne vs. negatywne skutki polityki; oddziaływanie endogeniczne vs. egzogeniczne polityki; efekt substytucyjny vs. efekt mnożnikowy polityki; efekty zrównoważone vs. krótkoterminowe. Ocena opierała się na danych jakościowych oraz ilościowych (Medeiros 2014).

${ }^{8}$ Analiza przepływów międzygałęziowych - „model ustalania ilościowych związków między różnymi sektorami produkcji, prowadzących do ogólnej równowagi gospodarczej” (Czyżewski, Grzelak, 2014, s. 22).
} 
darcze. Di Caro i in.(2018) przeprowadzili badania krótkookresowego wpływu regionalnych inwestycji (poziom NUTS2) w kapitał ludzki we Włoszech między 2007 a 2013 r. W badaniach użyto danych na temat ogólnego zatrudnienia, liczby osób korzystających z funduszu gwarancyjnego (ang. wage gaurantee fund) oraz stworzonego na potrzeby badania wskaźnika absorbcji środków europejskich. Według analizy modeli panelowych polityka wspierająca kapitał ludzki stanowiła poduszkę asekuracyjną w czasie kryzysu, a regiony najbardziej inwestujące w kapitał ludzki (Lombardia i Emilia-Romania) najlepiej poradziły sobie z kryzysem.

Szczególną grupą wymagającą wsparcia na rynku pracy w czasie kryzysu i po nim byli młodzi dorośli. Według danych Komisji Europejskiej (2013) między 2007 a 2011 r. 15 mln beneficjentów programów Funduszu Społecznego miało poniżej 25 lat. Przegląd literatury naukowej oraz treści programów europejskich przeprowadzony przez O’Reilly i in. (2015) pokazuje, że różne rodzaje interwencji wspierających kapitał ludzki oraz zatrudnienie wśród młodych dorosłych dają różne efekty. Na przykład, pomoc w znalezieniu pracy działa w krótkim okresie, sponsorowane szkolenia wykazują pozytywny wpływ w średnim okresie, subwencje dla pracowników na czasowe zatrudnienia są efektywne, ale kosztowne, a wspieranie start-upów wywiera pozytywny wpływ wyłącznie na wysoko wykształconych młodych dorosłych (O’Reilly i in. 2015). Innymi słowy interwencje wspierające kapitał ludzki wśród młodych dają bardzo zróżnicowane wyniki i zależą od wielu czynników.

Wiele badań nie wykazuje jednoznacznie pozytywnego wpływu polityki spójności na rozwój regionalny. Jak pokazały badania czeskich firm, w perspektywie mikroekonomicznej, wpływ szkoleń w ramach Europejskiego Funduszu Społecznego na rozwój przedsiębiorstw jest nikły lub nieistniejący (Pelucha i in. 2019). W badaniach obejmujących lata 2006-2012 zastosowano metody jakościowe i ilościowe. Uczestniczyły w nich firmy, które skorzystały oraz nie skorzystały z projektów grantowych, a przedmiotem analizy było to, czy uczestnictwo pracowników w szkoleniach wpłynęło na zyski przedsiębiorstw. Analiza wykazała, że nie szkolenia, lecz inne czynniki miały większy wpływ na rozwój firm: wewnętrze (np. zrozumienie celu szkolenia przez pracowników) i zewnętrzne czynniki (np. długość obecności na rynku).

Ponadto, badając aktywną politykę rynku pracy ${ }^{9}$, wspieraną przez Europejski Fundusz Społeczny, González-Alegre (2018) zwrócił uwagę na umiarkowany wpływ Funduszu na wspieranie inwestycji w politykę rynku pracy na polu krajowym. Przeanalizowano 17 hiszpańskich regionów między 1989 a 2010 r. Wyniki pokazały, że wsparcie Europejskiego Funduszu Społecznego nie jest wystarczającą motywacją dla samorządów do zwiększenia swoich wydatków na politykę wspierającą rynek pracy i kapitał ludzki. Czynnikiem mobilizującym do zwiększenia wydatków

${ }^{9}$ Według Laurisza (2009, s. 75) aktywna polityka pracy ma prowadzić „do zwiększenia zatrudnienia i spadku bezrobocia wśród osób objętych programami aktywizującymi” oraz oddziaływać szerzej na społeczeństwo. 
okazało się natomiast naśladownictwo sąsiednich regionów, które zdecydowały się na większe wsparcie finansowe (González-Alegre 2018). Badania González-Alegre (2018) sugerują więc, że pomoc Unii nie jest wystarczającą motywacją do pogłębiania wsparcia w zakresie kapitału ludzkiego. Znalezienie wytłumaczenia, dlaczego nie ma związku między środkami unijnymi a lokalną polityką, wymaga pogłębionych badań, jednak jednym z możliwych tłumaczeń może być to, że kapitał ludzki nie jest priorytetem inwestycyjnym dla wielu krajów Unii Europejskiej, co w swojej pracy pokazuje Medve-Bálint (2018).

Badania Medve-Bálint (2018) poddały analizie dopasowanie wydatków polityki spójności do potrzeb rozwojowych danego kraju. Dotyczyły one krajów Europy Wschodniej i Południowej dwóch okresów polityki spójności, lat 2007-2013 oraz 2014-2020 (Medve-Bálint, 2018). Zbadano poziom rozwoju każdego z państw w następujących dziedzinach: kapitału fizycznego, kapitału ludzkiego, badań i rozwoju, wsparcia biznesu oraz jakość instytucji, i porównano z wydatkami w ramach polityki spójności w każdym z tych obszarów. Analiza wykazała, że w badanych krajach najwięcej środków wydano na infrastrukturę fizyczną, co jest sprzeczne z długofalowymi potrzebami rozwojowymi, dla których bardziej odpowiednie byłyby wydatki na rozwój i badania oraz kapitał ludzki (Medve-Bálint 2018). Trzeba mieć na uwadze ograniczenia tej metody, o których wspomina z resztą sam autor, wskazując na względność krajowych potrzeb rozwojowych oraz problem zmian kategorii wydatkowania w różnych okresach programowania, co utrudnia analizę.

Rolę otoczenia oraz holistycznego podejścia do kwestii emigracji wykształconych mieszkańców podkreśla zlecona przez Europejski Komitet Regionów analiza europejskich polityk lokalnych dot. drenażu mózgów (Cavallini i in. 2018). Autorzy twierdzą, że polityka przeciwdziałająca temu procesowi powinna opierać się na analizie i konsultacjach z grupami najbardziej dotkniętymi tym problemem oraz kluczowymi aktorami lokalnego rozwoju (Cavallini i in. 2018). Ponadto, drenaż mózgów nie występuje w izolacji, tylko w jednym mieście lub gminie, dlatego sąsiednie gminy, które borykają się z podobnymi problemami, powinny opracować wspólną strategię rozwiązania tego problemu (Cavallini i in. 2018). Innymi słowy, polityka retencji i rozwoju kapitału ludzkiego powinna być częścią szerszej strategii rozwoju, wykorzystującej synergię z innymi obszarami polityki lokalnej.

\section{Podsumowanie}

Podstawowy wniosek, jaki można wysnuć z powyższego przeglądu, jest taki, że metody badawcze oraz dobór danych znacząco kształtują ocenę efektywności polityki spójności oraz inwestycji w kapitał ludzki. Co więcej, różnice w podejściach badanie efektywności vs. dopasowania inwestycji do faktycznych potrzeb - dają 
różne obrazy skuteczności funduszy unijnych. Chociaż analiza konwergencji cieszy się największą popularnością, powyższy przegląd literatury pokazuje istotną wartość, jaką mają inne rodzaje badań. Polityka spójności jest przede wszystkich programem inwestycyjnym, ale ignorowanie jej wpływu na lokalną i regionalną administrację daje niepełny obraz rzeczywistości. Prace Medve-Bálint (2018) oraz Churskiego i in. (2016) zwracają uwagę na rozdźwięk między potrzebami rozwojowymi a wydatkami. Natomiast praca González-Alegre (2018) pokazuje, że inwestycje w ramach polityki spójności nie idą w parze ze zmianami polityki regionalnej, a tym samym być może minimalizują długotrwałą efektywność inwestycji współifnansowanych przez UE.

Ponadto, skuteczność polityki spójności we wspieraniu rozwoju regionalnego nie jest uniwersalna. Czynnikami kształtującymi relację Fundusze Strukturalne - rozwój są: regionalne i państwowe środowisko instytucjonalne, okres przyznawania środków, poziom rozwoju oraz obszar wsparcia. Według Rodríguez-Pose i Fratesi (2004) obszarem wsparcia o największym potencjale rozwojowym jest kapitał ludzki. Podobnie jak w przypadku badań ogólnego wpływu polityki spójności, inwestycje w ramach Europejskich Funduszy Strukturalnych wspierające rozwój kapitału ludzkiego mogą stymulować rozwój lokalny i regionalny, ale pod pewnymi warunkami. Skuteczność inwestycji zależy od charakteru lokalnego rynku pracy i sektorów gospodarczych, a każdy ich rodzaj inaczej oddziałuje na beneficjentów i ich otoczenie. Należy także pamiętać, że inwestycje w kapitał ludzki mogą mieć również negatywne skutki dla regionu - odpływ najlepiej wykształconych mieszkańców i spadek potencjału rozwojowego (Herbst, Rok 2013).

Pomimo dużej ilości badań na temat polityki spójności w ogóle nadal brakuje analiz łączących politykę Unii Europejskiej z badaniami nad kapitałem ludzkim. Dzisiejszy stan wiedzy nie pozwala na szeroko zakrojoną analizę porównawczą sytuacji w różnych krajach. Co więcej, wyciągnięcie wniosków na temat wpływu kapitału ludzkiego i funduszy unijnych na rozwój jest o tyle trudne, że większość badań anglojęzycznych nie schodzi na niższy niż NUTS 2 poziom analizy. Dall'Erba i Fang (2017) wskazują również, że dotychczasowe analizy polityki spójności ograniczone były do badania efektów średnio- lub krótkookresowych. Potrzeba więc dalszych badań poświęconych analizie efektów długofalowych. Ponadto, wyniki badań Pelucha i in. (2019) dotyczących czeskich firm oraz analiza dokumentów O'Reilly i in. (2015) pozostawiają niedosyt wiedzy na temat jakości interwencji (szkoleń i innych programów). Potrzeba więc więcej pogłębionych badań jakościowych zwracających uwagę na jakość interwencji i zróżnicowanie między nimi.

Rekomendacje dla środowiska akademickiego płynące $\mathrm{z}$ tego przeglądu są więc następujące. Badania nad polityką spójności należy rozumieć szerzej i badać nie tylko jej wpływ na konwergencję, ale także na administrację regionalną i prowadzoną przez nią politykę rozwoju; po drugie, metody przestrzenne oferują szerokie spojrzenie na dynamikę interwencji publicznych wychodzącą poza sztywne granice administracyjne, 
a metody jakościowe umożliwiają istotny wgląd w jakość interwencji; i po trzecie, korzystając z pozytywnych zmian w dostępności danych statystycznych, należy zwrócić większą uwagę na badania efektów długookresowych oraz analizy na poziomie lokalnym (poniżej NUTS2), również do międzynarodowych porównań.

Konkluzje cytowanych autorów wywołują także pewne refleksje dotyczące polityki regionalnej oraz rekomendacje dla instytucji tworzących politykę regionalną i zarządzających funduszami UE. Po pierwsze, pomimo obiecujących wyników badań prowadzonych przez ostatnie 60 lat, inwestycje w kapitał ludzki same w sobie nie stanowią klucza do sukcesu rozwoju regionalnego. Ze względu na mobilność pracowników i konkurencyjność dużych ośrodków miejskich inwestowanie tylko w wykształcenie może prowadzić do drenażu mózgów. Co więcej, jak pokazują badania np. Medve-Bálint (2018) czy González-Alegre (2018), dostępność środków na potrzeby inwestycji w kapitał ludzki nie oznacza, że zostaną one wpełni wykorzystane i zmobilizują dodatkowe wsparcie regionalnego rozwoju.

Badania potwierdzają zasadność traktowania kapitału ludzkiego jako kluczowego, choć niejedynego, czynnika rozwoju. Oprócz inwestycji w kapitał ludzki należy np. wspomagać przedsiębiorczość oraz przyciągać i zatrzymywać talenty w regionie. Zalecenia Cavallini i in. (2018) dotyczące drenażu mózgów mogą odnosić się więc również do inwestowania w kapitał ludzki w ogóle, ponieważ to właśnie dogłębne zrozumienie problemów, potrzeb rozwojowych oraz współpraca na poziomie lokalnym i regionalnym pozwoli na osadzenie inwestycji w kapitał ludzki w szerszym kontekście rozwoju regionalnego i pozwoli na maksymalizację zysków z tych działań.

Na koniec wypadałoby dodać komentarz na temat trwającego kryzysu wywołanego przez pandemię COVID-19. Potrzeba wspierania najbardziej dotkniętych sektorów (opieka zdrowotna, zarządzanie kryzysowe itd.) stwarza nowe wyzwania dla nowego okresu programowania polityki spójności oraz roli inwestycji w kapitał ludzki. Trwający kryzys bez wątpienia wpłynie na rozwój europejskich regionów. Jednocześnie, w ramach nowego wieloletniego budżetu UE (2021-2027) można spodziewać się dodatkowych środków na odbudowę gospodarczą oraz zwiększenia elastyczności funduszy polityki spójności (Rada Europejska 2020; Komisja Europejska 2020d; Komisja Europejska 2020e). Nie umniejszając w niczym skali dramatu spowodowanego przez pandemię, można uznać, że wymuszone zmiany w strukturze funduszy mogłyby zostać potraktowane przez instytucje regionalne i lokalne jako szansa na redefinicję strategii rozwoju oraz maksymalizację korzyści, jakie zapewniają środki unijne.

Artykuł powstał w ramach finansowanego przez Narodowe Centrum Nauki projektu badawczego „Inwestowanie w kapitał ludzki a lokalny rozwój społeczno-gospodarczy. Analiza empiryczna skutków interwencji publicznej na przykładzie wykorzystania funduszy strukturalnych UE w Polsce” (2015/17/B/HS5/00462). 


\section{Literatura}

Aghion P., Akcigit U., Howitt P., 2015, The Schumpeterian growth paradigm, Economics, 7 (1), $557-575$.

APA, 2020, Autoregressive Model APA Dictionary of Psychology, https://dictionary.apa.org/autoregressive-model (dostęp: 26.07.2020).

Bachtler J., Begg I., 2018, Beyond Brexit: Reshaping policies for regional development in Europe, Papers in Regional Science, 97 (1), 151-170.

Becker S.O., Egger P.H., von Ehrlich M., 2018, Effects of EU regional policy: 1989-2013, Regional Science and Urban Economics, 69, 143-152.

Bradley J., 2006, Evaluating the impact of European Union cohesion policy in less-developed countries and regions, Regional Studies, 40 (2), 189-200.

Caldas P., Dollery B., Marques R.C., 2018, European cohesion policy impact on development and convergence: a local empirical analysis in Portugal between 2000 and 2014, European Planning Studies, 26 (6), 1081-1098.

Cavallini S., Soldi R., Di Matteo L., Alina Utma M.A., Errico B., 2018, Addressing brain drain: The local and regional dimension. European Committee of the Regions.https://cor.europa.eu/en/ engage/studies/Documents/addressing-brain-drain/addressing-brain-drain.pdf (dostęp: 26.07.2020).

Cerqua A. , Pellegrini G., 2018, Are we spending too much to grow? The case of Structural Funds, Journal of Regional Science, 58 (3), 535-563.

Churski P., Perdał R., Herodowicz T., 2016, Rola środków polityki spójności pozyskiwanych prжez samorzqd terytorialny w rowwoju spoteczno-gospodarczym ośrodkow regionalnych w Polsce, Samorząd Terytorialny, (7-8), 96-115.

Cichy K., Malaga K., 2007, Kapitat Ludzki w modelach i teorii wzrostu gospodarczego, [w:] Herbst M. (red.), Kapitat ludzki i kapitat spoteczny a rozwój regionalny, Warszawa: Wydawnictwo Naukowe Scholar, 18-53.

Cohen D., Soto M., 2007, Growth and human capital: good data, good results, Journal of Economic Growth, 12 (1), 51-76.

Cuaresma J.C., Doppelhofer G., Huber F., Piribauer P., 2018, Human capital accumulation and long-term income growth projections for European regions, Journal of Regional Science, $58(1), 81-99$.

Czyżewski A., Grzelak A., 2014, Przeptywy międzygatęziowe jako makroekonomiczny model gospodarki - doświadczenia i przyszłość, Roczniki Ekonomiczne Kujawsko-Pomorskiej Szkoły Wyższej w Bydgoszczy, (7), 21-32.

Dall'Erba S., Fang F., 2017, Meta-analysis of the impact of European Union Structural Funds on regional growth, Regional Studies, 51 (6), 822-832.

Di Caro P., Arbolino R., Marani U., 2018, A note on the effects of human capital policies in Italy during the Great Recession, Economics Bulletin, 38 (3), 1302-1312. 
Di Cataldo M., Rodríguez-Pose A., 2017, What drives employment growth and social inclusion in the regions of the European Union?, Regional Studies, 51 (12), 1840-1859.

Di Cataldo M., 2017, The impact of EU Objective 1 funds on regional development: Evidence from the U.K. and the prospect of Brexit, Journal of Regional Science, 57 (5), 814-839.

Di Liberto A., Symons J., 2001, Education and Italian Regional Development, London: Centre for Economic Performance, London School of Economics and Political Science.

Ederveen S., Groot H.L.F., Nahuis R., 2006, Fertile Soil for Structural Funds? A panel data analysis of the conditional effectiveness of European cohesion policy, Kyklos, 59 (1), 17-42.

Eurostat, 2020, Glossary: EU enlargements. https:/ec.europa.eu/eurostat/statistics-explained/ index.php/Glossary: EU_enlargements (dostęp: 21.06.2020).

Fiaschi D., Lavezzi A.M., Parenti A., 2018, Does EU cohesion policy work? Theory and evidence, Journal of Regional Science, 58 (2), 386-423.

Fratesi U., Wishlade F.G., 2017, The impact of European cohesion policy in different contexts, Regional Studies, 51 (6), 817-821.

Gennaioli N., La Porta R., Lopez-de-Silanes F., Shleifer A., 2013, Human capital and regional development, The Quarterly Journal of Economics, 128 (1), 105-164.

González-Alegre J., 2018, Active labour market policies and the efficiency of the European Social Fund in Spanish regions, Regional Studies, 52 (3), 430-443.

Gorzelak G., 2014, Wykorzystanie środków Unii Europejskiej dla rozwoju kraju - wstępne analizy, Studia Regionalne i Lokalne, 3 (57), 5-24.

Herbst M., Rok J., 2013, Mobility of human capital and its effect on regional economic development. Review of theory and empirical literature, Munich Personal RePEc Archive.

Herbst M., 2007a, Kapitat ludzki, dochód i wrrost gospodarczy w badaniach empirycznych, [w:] Herbst M. (red.), Kapitat ludzki i kapitat spoteczny a rozwój regionalny, Warszawa: Wydawnictwo Naukowe Scholar, 98-125.

Herbst M., 2007b, Wptyw kapitatu ludzkiego i spotecznego na (krótkookresowy) wærost gospodarczy w polskich podregionach, [w:] Herbst M. (red.), Kapitat ludzki i kapitat spoteczny a rozwój regionalny, Warszawa: Wydawnictwo Naukowe Scholar, 166-203.

Komisja Europejska, 2020a, Glossary:CCohesion policy, https://ec.europa.eu/regional_policy/en/ policy/what/glossary/c/cohesion-policy (dostęp: 12.04.2020).

KomisjaEuropejska, 2020b, Cohesion policy. Frequently asked questions https://ec.europa.eu/ regional_policy/en/faq/\#3 (dostęp: 12.04.2020).

KomisjaEuropejska, 2020c, RegionalPolicy - Education and training, https://ec.europa.eu/ regional_policy/en/policy/themes/education-training/(dostęp: 26.07.2020).

Komisja Europejska, 2020d, Budżet UE dla odbudowy gospodarki: Pytania i odpowiedzi dotyczace REACT-EU, polityki spójności po 2020 r. i Europejskiego Funduszu Spotecznego+, https://ec.europa.eu/commission/presscorner/detail/pl/qanda_20_948 (dostep: 17.08.2020).

Komisja Europejska, 2020e, Regional policy newsroom: Commissioner Ferreira welcomes the political agreement on the EU cohesion policy legislative package 2021-2027, https://ec.europa. eu/regional_policy/en/newsroom/news/2020/12/16-12-2020-commissioner-ferreira-wel- 
comes-the-political-agreement-on-the-eu-cohesion-policy-legislative-package-2021-2027 (dostęp: 21.02.2021).

Komisja Europejska, 2013, EU cohesion policy contributing to employment and growth in Europe, Directorates-General for Regional, Urban Policy and Employment, Social Affairs, Inclusion, Unia Europejska.

Kozak M., 2014, 10 lat polityki spójności w Polsce, Studia Regionalne i Lokalne, 4 (58), 25-50. Laurisz N., 2009, Czy aktywna polityka rynku pracy jest skuteczna? Zarządzanie Publiczne, 4, 73-91.

Lucas R., 1988, On the mechanics of economic development, Journal of Monetary Economics, 22, 3-42.

Mankiw N.G., Romer D., Weil D., 1992 A contribution to the empirics of economic growth, Quarterly Journal of Economics, 107, 407-437.

Männasoo K., Hein H., Ruubel R., 2018, The contributions of human capital, RæD spending and convergence to total factor productivity growth, Regional Studies, 52 (12), 1598-1611.

Maynou L., Saez M., Kyriacou A., Bacaria J., 2016, The impact of structural and cohesion funds on Eurozone Convergence, 1990-2010, Regional Studies, 50 (7), 1127-1139.

Medeiros E., 2014, Assessing territorial impacts of the EU cohesion policy: The Portuguese case, European Planning Studies, 22 (9), 1960-1988.

Medeiros E., 2017, European Union cohesion policy and Spain: a territorial impact assessment, Regional Studies, 51 (8), 1259-1269.

Medve-Bálint G., 2018, The cohesion policy on the EU's eastern and southern periphery: Misallocated Funds? Studies in Comparative International Development, 53 (2), 218-238.

Mincer J., 1958, Investment in human capital and personal income distribution, Journal of Political Economy, 66, 281-302.

Mohl P., Hagen T., 2010, Do EU structural funds promote regional growth? New evidence from various panel data approaches, Regional Science and Urban Economics, 40 (5), 353-365.

Nelson R., Phelps E., 1966, Investment in humans, technological diffusion, and economic growth, American Economic Review, 56, 69-75.

O’Reilly J., Eichhorst W., Gábos A., Hadjivassiliou K., Lain D., Leschke J., McGuinness S., Kureková L.M., Nazio T., Ortlieb R., Russell H., 2015, Five characteristics of youth unemployment in Europe, SAGE Open, 5 (1), 1-19.

Pelucha M., Kveton V., Potluka O., 2019, Using mixed method approach in measuring effects of training in firms: Case study of the European Social Fund support, Evaluation and Program Planning, 73, 146-155.

Rada Europejska, 2020, Special meeting of the European Council (17, 18, 19, 20 and 21 July 2020) Conclusions, https://www.consilium.europa.eu/media/45109/210720-euco-final-conclusions-en.pdf (dostęp:15.08.2020).

Rodríguez-Pose A., Fratesi U., 2004, Between development and social policies: The Impact of European Structural Funds in Objective 1 Regions, Regional Studies, 38(1), 97-113.

Telega I., 2012, Trwatośc w modelu wrostu Solowa. Analiza krytyczna, Polskie Towarzystwo Ekonomiczne, Zeszyty Naukowe 12, 21-33. 
Uzawa H., 1965, Optimum technical change in an aggregative model of economic growth, International Economic Review, 6, 18-31.

Wojnar K., 2011, Wptyw polityki spójności na spójność spoteczna polskich miast - wnioski z badań ewaluacyjnych, Studia Regionalne i Lokalne, Wydanie Specjalne 2011, 67-83.

Wanda Biedka

wanda.biedka@gmail.com 